\title{
Aggressive presentation of plasmablastic myeloma
}

\author{
Jaime Andres Suarez-Londono, Abhinav Rohatgi, Crystal Antoine-Pepeljugoski, \\ Marc J Braunstein
}

Department of Medicine, Division of OncologyHematology, NYU Long Island School of Medicine, NYU Winthrop Hospital, Mineola, New York, USA

\section{Correspondence to} Dr Marc J Braunstein; marc.braunstein@nyulangone. org

Accepted 23 March 2020

\section{DESCRIPTION}

A 53-year-old HIV-negative man presented to the emergency room with a month of testicular pain, rapidly enlarging testes, night sweats and unintentional weight loss. He did not report any recent travel or sick contacts. Physical examination was remarkable for bilaterally enlarged testes to $8 \mathrm{~cm}$ and T7 dermatomal sensory loss. Pertinent laboratory studies revealed: haemoglobin $113 \mathrm{~g} / \mathrm{L}$ (reference range, 135-180), IgG-lambda M-spike 3.4 g/dL and lactate dehydrogenase (LDH) $705 \mathrm{IU} / \mathrm{L}$ (reference range, 140-280). Positron emission tomography/ computed tomography (PET/CT) (figure 1) showed hypermetabolic testicular masses, extensive lytic bone lesions, epidural metastases at T7, T8, T12 and L3 with cord impingement at T7-T8, and a large left iliac mass, and bilateral perinephric masses. Biopsy of a perinephric mass showed atypical cells with lambda light-chain restricted plasma cells. A bone marrow biopsy (figure 2A) showed 40\% anaplastic plasmacytoid cells with pleomorphic morphology consistent with plasmablastic myeloma. The large plasmablastic cells were CD38(+), CD138(+),

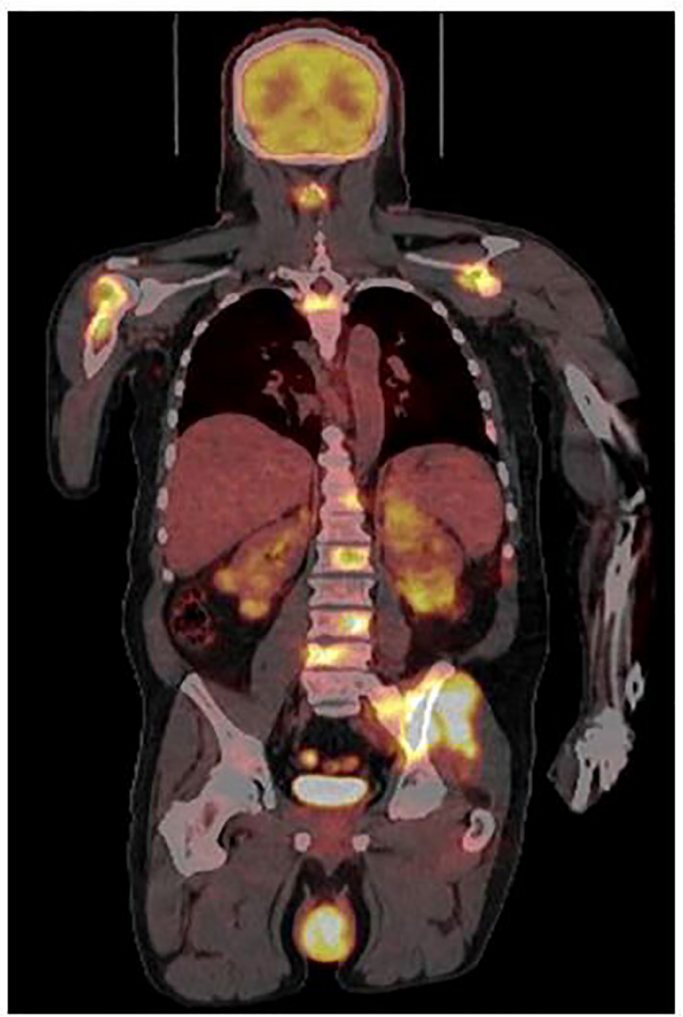

Figure 1 Positron emission tomography/computed tomography (PET/CT) results. PET-avid areas showing diffuse skeletal and soft tissue uptake.
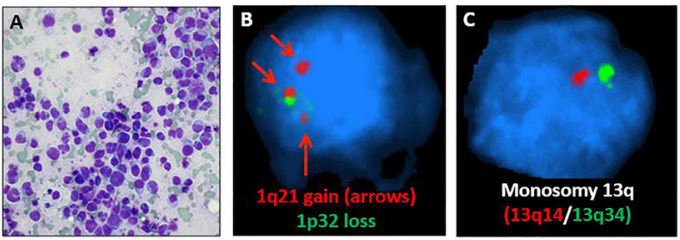

Figure 2 Pathologic findings. Morphology of plasmablastic cells on bone marrow aspiration (A) and cytogenetic abnormalities on fish showing gain of 1q21 and loss of 1 p32 (B) as well as deletion 13q (C).

MUM1(+), CD20(-), CD30(-), CD45(-), PAX-5(-), ALK-1(-), EBER-ISH(-) and HHV8(-), with a high Ki-67 staining $90 \%$ of the cells. Fluorescent in situ hybridization (FISH) was pertinent for chromsomes $13 \mathrm{q}$ deletion, $1 \mathrm{p}$ deletion and trisomy 1q (figure $2 \mathrm{~B}$ and $\mathrm{C}$ ), which are commonly associated with multiple myeloma. The differential diagnosis included plasmablastic myeloma, plasmablastic lymphoma and anaplastic myeloma. Given the bone marrow morphology, extranodal findings, lack of Epstein Barr Virus (EBV) and Human Herpesvirus-8 (HHV8) involvement, as well as myeloma-associated FISH abnormalities, the diagnosis was more consistent with plasmablastic myeloma. Following a short course of external radiation to the T7-T8 spine, systemic treatment included a combination of the anti-CD38 monoclonal antibody daratumumab along with cyclophosphamide, doxorubicin, vincristine, and prednisone every 3 weeks, which resulted in partial response after three cycles, indicated by a reduction M-spike to $0.7 \mathrm{~g} / \mathrm{dL}$. In addition, his total IgG decreased from 5.6 to $1.1 \mathrm{~g} / \mathrm{dL}$, serum lambda light chain decreased from 460 to $76 \mathrm{mg} / \mathrm{dL}$. Unfortunately, he later decompensated due to severe sepsis secondary to pneumonia, leading to respiratory failure and death.

Plasmablastic myeloma is rare and morphologically similar to plasmablastic lymphoma, but is typically EBV-negative, and portends a poor prognosis with a reported median survival of 10 months. ${ }^{12}$ Given the low incidence of plasmablastic myeloma, there is no consensus on management of newly diagnosed patients. Treatment typically includes a combination of modern anti-myeloma agents, such as the proteasome inhibitor bortezomib, along with chemotherapy. ${ }^{3}$ In the Myeloma E9486 trial, the largest interventional study on plasmablastic myeloma, treatment with vincristine, carmustine, melphalan, cyclophosphamide and prednisone showed a response rate of $47 \%{ }^{1}$ To the best of our knowledge this is the first report of plasmablastic myeloma treated with a regimen that included daratumumab, which resulted in a partial response. An ongoing early phase 
1 clinical trial (NCT04139304) is examining the benefit of daratumumab combined with etoposide, prednisone, vincristine, cyclophosphamide and doxorubicin.

\section{Learning points}

- Plasmablastic myeloma is a rare and aggressive neoplasm presenting with overlapping features of multiple myeloma and non-Hodgkin's lymphoma.

- There is no consensus on the management of plasmablastic myeloma.

- When combined with chemotherapy, the anti-CD38 monoclonal antibody daratumumab may effectively target plasmablastic myeloma cells.

Twitter Marc J Braunstein @docbraunstein

Contributors JAS-L and MJB both managed the patient and drafted the manuscript. AR and CA-P helped draft the manuscript.
Funding The authors have not declared a specific grant for this research from any funding agency in the public, commercial or not-for-profit sectors.

Competing interests MJB reports research funding from Janssen and serves on advisory boards for Amgen, AstraZeneca, Celgene, Janssen, Karyopharm, Takeda and Verastem. JAS-L has served on advisory boards for Amgen, AstraZeneca, Celgene and Verastem.

Patient consent for publication Next of kin consent obtained.

Provenance and peer review Not commissioned; externally peer reviewed.

\section{ORCID iD}

Marc J Braunstein http://orcid.org/0000-0002-0859-7257

\section{REFERENCES}

1 Greipp PR, Leong T, Bennett JM, et al. Plasmablastic morphology--an independent prognostic factor with clinical and laboratory correlates: Eastern Cooperative Oncology Group (ECOG) myeloma trial E9486 report by the ECOG Myeloma Laboratory Group. Blood 1998:91:2501-7.

2 Greipp PR, Raymond NM, Kyle RA, et al. Multiple myeloma: significance of plasmablastic subtype in morphological classification. Blood 1985;65:305-10.

3 Castillo JJ, Bibas M, Miranda RN. The biology and treatment of plasmablastic lymphoma. Blood 2015;125:2323-30.

Copyright 2020 BMJ Publishing Group. All rights reserved. For permission to reuse any of this content visit

https://www.bmj.com/company/products-services/rights-and-licensing/permissions/

BMJ Case Report Fellows may re-use this article for personal use and teaching without any further permission.

Become a Fellow of BMJ Case Reports today and you can:

- Submit as many cases as you like

- Enjoy fast sympathetic peer review and rapid publication of accepted articles

- Access all the published articles

- Re-use any of the published material for personal use and teaching without further permission

\section{Customer Service}

If you have any further queries about your subscription, please contact our customer services team on +44 (0) 2071111105 or via email at support@bmj.com.

Visit casereports.bmj.com for more articles like this and to become a Fellow 